\title{
Palaeobotanical Study on Soil Strata of Lake Qarun Shore since Helleno-Roman Period
}

\author{
Mosalam Shaltout ${ }^{1}$ and Mohamed Azzazi ${ }^{2}$ \\ 1. NRIAG (National Research Institute of Astronomy and Geophysics), Solar and Space Department, Helwan, Cairo 11421, Egypt \\ 2. ESRI (Environmental Studies and Research Institute), Sadat City University, Sadat City 32897, Egypt
}

Received: January 15, 2015 / Accepted: January 25, 2015 / Published: February 25, 2015.

\begin{abstract}
The present study is an attempt to apply the concept of plant and pollen indicators to habitat conditions in different soil strata at archaeological site (Lake Qarun). It revealed a great palaeoenvironmental information's about habitat changing of Lake Qarun from a humid and wet conditions during the Hellenic Period to reed swampy early Roman, to Nile Flooding middle Roman, to mesophytic habitats Late Roman, also changing to halophytic and salt marshes with presence of Chenopodiaceae at recent time. Using indicator plants and their remains i.e. pollen grains and spores, palynological studies of different soil strata revealed that, presence of 13 pollen and spore types e.g. Lycopodium, Typhaceae type, Juncaceae, Poaceae, Cyperaceae, Caryophyllaceae, Chenopodiaceae, Nymphaeaceae, Fabaceae, Asteraceae, Tamaricaceae,Onagraceae and Lamiaceae. The data obtained were valuable in reconstruct past vegetation and habitats conditions of Lake Qarun during Helleno Roman period.
\end{abstract}

Key words: Lake Qarun, Palynology, Soil Strata, Graeco Roman, fossil pollen.

\section{Introduction}

Pollen as a part of the reproductive system of plants are tiny grains discharged like dust from the male plant and rely on wind and insects to be transported to female plants. Pollen grains are distinctive to each plant species and sub-species, and their tiny and dense structure mean that they may survive in many soil types for thousands of years [1]. The pollen analysis, vegetation history study using microfossils provide useful information about the environmental conditions in the present and past. The outside of the pollen grain wall is made of highly resistant material, so, the pollen from 400 million years ago can be found today. Each pollen and spore is different in shape and structure, thus the morphology is a key to understanding the types of vegetation. Pollen analysis was first produced by the Swedish geologist Von Post in about 1916. From the pollen diagram, information can be obtained about vegetation, floristic composition, changes, lake

Corresponding author: Mosalam Shaltout, professor, research fields: space physics, space weather, astronomy. E-mail: mosalam_shaltout@yahoo.com. sedimentation, wind direction, turnover rate of the lake ecosystem and sea levels too [2]. Palynological investigations were introduced to the Egyptian archaeological sites e.g. Mehringer [3], who studied the sediments and fossil pollen of two short cores at Birket Qarun in Fayum, Egypt. The data obtained reflect the Nile floods, lake levels, and agricultural developments of the last 325 years, demonstrate the potential of detailed record from the Fayum Depression. The chronology of these cores is inferred by correlation of historic events with changes in the fossil and sedimentary records. The analysis revealed abundant pollen of shallow water, rooted aquatic plants e.g. (Typhoo pollen type) provides evidence for continued low lake levels through 1700s. A high lake level, resulting from the extreme Nile flood of 1817-1818, is recorded by hystrichospheres, reworked by wave action, from Eocene marine sediments exposed on the north shore of Birket Qarun. Also, Mehringer [3] added that, the political administrations, as reflected in agricultural policy, is also recorded in lake history. Changing lake levels are, in part, correlated 
with canal neglect during Malmo and Ottoman control, and renewed canal maintenance under the agricultural policy of Mohamed Aly. Few studies were carried out on palynological, archaeobotanical e.g. Mehringer [3], who study the introduced plants during Mohammed Aly Policy of agriculture at Lake Qarun.

\subsection{This Study Objective Includes:}

- Clarify the plant habitat changes since Greco-Roman period, using pollen analysis.

- To reveal the Nile flooding, using indicator plants and their pollen.

- Reconstruct vegetation history of Lake Qarun.

- The present study is an attempt to apply the concept of plant and pollen indicators to habitat conditions in different soil strata at archaeological site (Lake Qarun)

\subsection{History of Lake Qarun}

Lake Qarun (Birket Qarun) in Fayoum-Egypt, located about 80 kilometers southwest of Cairo in the Egyptian Fayoum not far from the Nile Valley, is one of Egypt's most treasured natural landmarks and a resource that has helped support human culture for some 8,000 years. It is the only natural contemporary lake of any size in Middle Egypt. It is therefore rich in both natural and archaeological resources. In reality, Lake Qarun is a huge salty body of water that makes it unfit for drinking. And while its southern and eastern shores are populated, where fresh water can be brought from irrigation systems, the northern shore is bare desert, uninhibited, and difficult to reach. The lake has an interesting history and there are some fascinating theories about how it came to be known as Lake Qarun. The lake and the nearby Qaser Qarun are said to take their names from the Greco-Roman city of Karanis to the east. However, the lake was known in the thirteenth century, some eight hundred years after the abandonment of Karanis, as Birka El Seid, or "the lake of fishing" in Arabic. Therefore, many believe that it is unlikely that Karanis would today. Late Roman period. Many Ptolemaic (Greek) and Roman towns were situated here. Furthermore, much of the area was cultivated until the decay of the Roman Empire, when local governmental mismanagement led to the loss of fertile land to the desert and the abandonment of the towns. Even recent reclamation work, which has made the southwestern shore of the lake green again, has failed to make good the huge losses of agricultural land incurred during the late Roman times. Qarun may thus have been a particularly unpopular Roman governor under whose careless rule this land was deserted, or else a fictional character epitomizing the Roman administration in general. The biblical and Quranic connections were probably added later when the similarity between the two stories was noticed. The Lake Qarun today, 45 meters below sea level, has a surface area of 214 square kilometers. It has a maximum depth of just over 8 meters (west of Golden Horn Island) and a volume of 800 million cubic meters. It is 42 kilometers long and 9 kilometers wide at its broadest point. About 370 million cubic meters of drainage water reach the lake annually, and as the lake level now stays fairly constant and there are no known outlets, this figure is also taken as the annual rate of evaporation. If follows that, if the water supply to the lake were cut off, it would dry up in two years. The high rate of evaporation has led to a concentration of salts, the lake is now as saline as the seawater, with a ratio of around 34.5 parts per thousand, said to be growing at the rate of 0.4 parts per year. For comparison, sea water ranges between 34 and 37 per thousand, while Jordan's Dead Sea has between 300 and 330 per thousand. The water is less salty in the East and the South of the lake, where the two main canals bring in fresh and drainage water.

\section{Materials and Methods}

Three profile sectors were dug to $120 \mathrm{~cm}$ depth, at three locations of Lake Qarun shore, soil samples were taken every $10 \mathrm{~cm}$. Chronology of soil strata was obtained by Austrian Mission for archaeological 


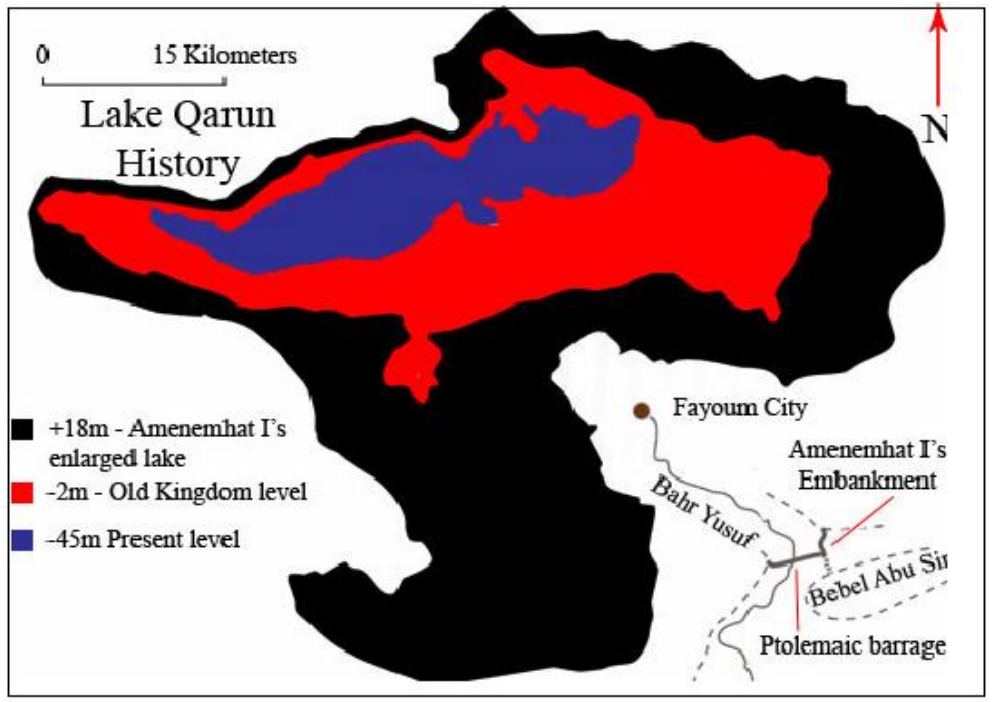

Fig. 1 Historical map of Lake Qarun.

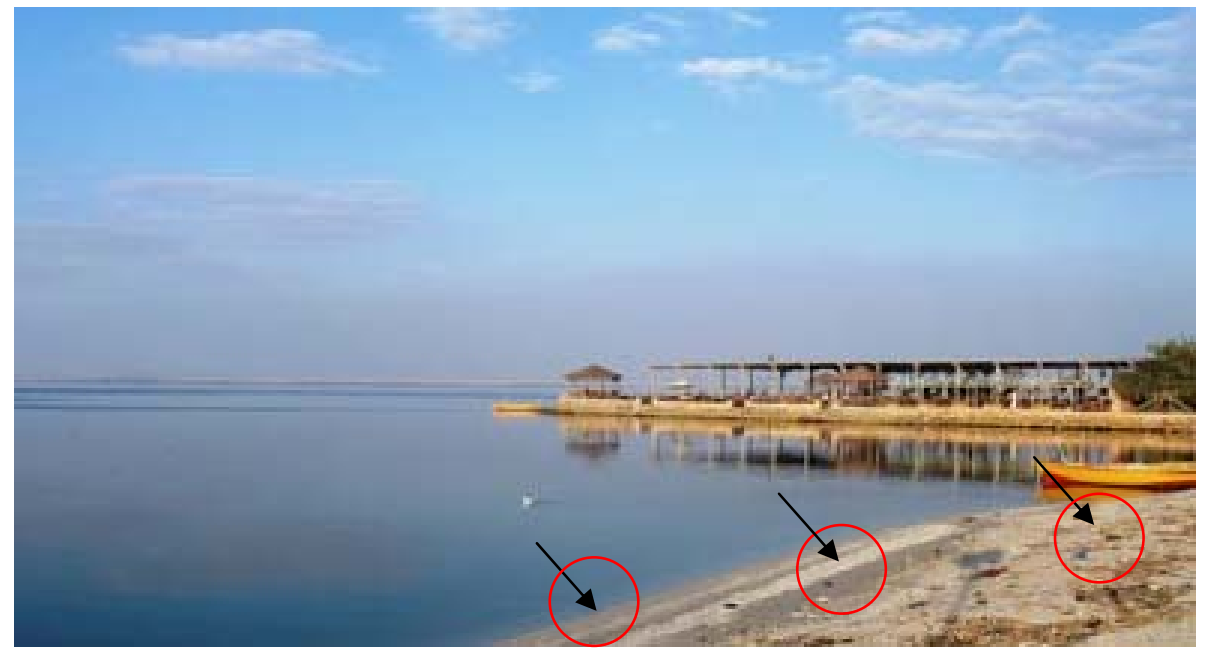

Fig. 2 Lake Qarun view from the eastern side (arrows indicate sampling locations).

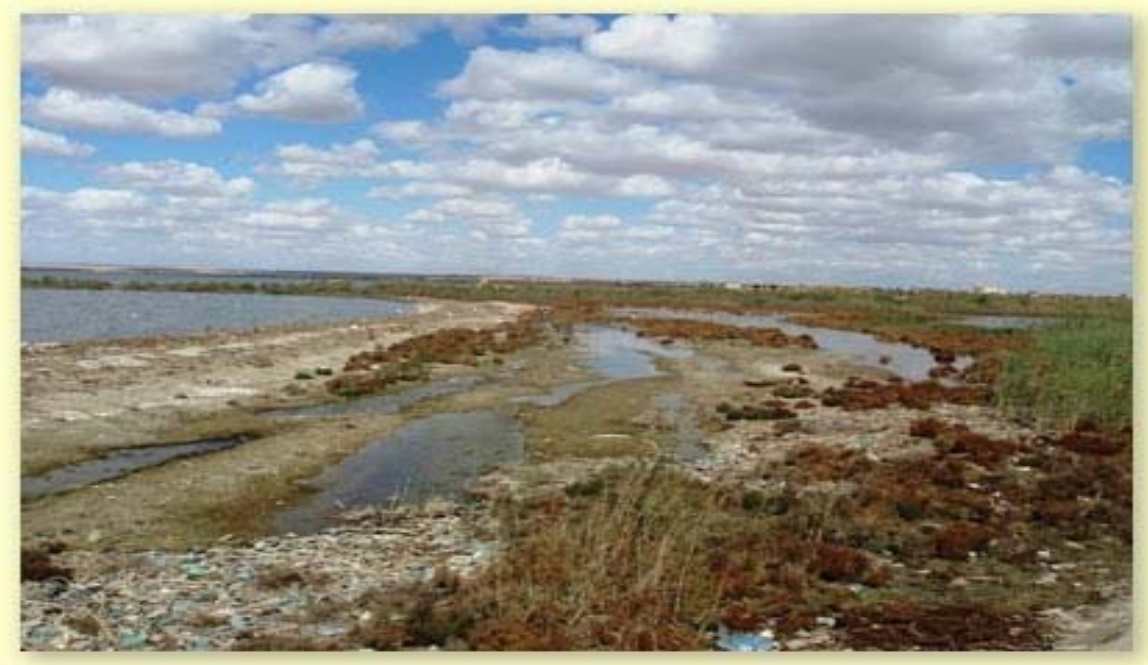

Fig. 3 Marshes along the Eastern edge of the lake. 


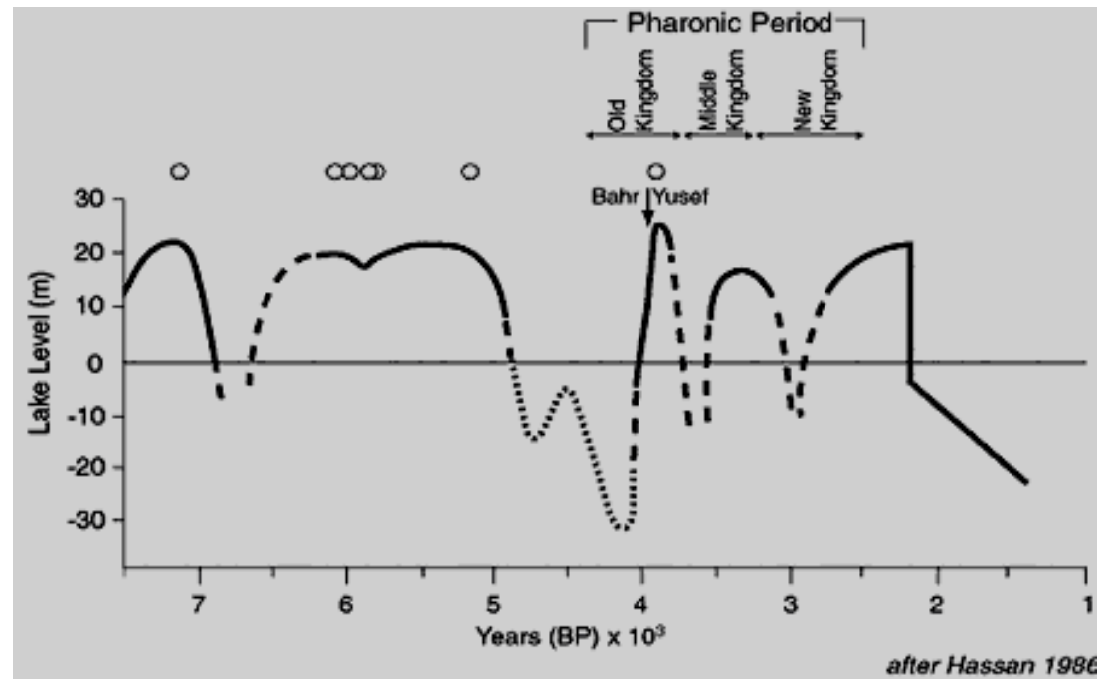

Fig. 4 Lake Level during (Pharaonic Period) [4].

excavations at Sharkiya Province. The soil samples were extracted for their pollen content, sieved according to Faegri [5]. Ten gm of soil were taken from the required sector level. Five gm (sub-sample) were placed in boiling thermoplastic tube, mixed with $10 \mathrm{ml} \mathrm{KOH} \mathrm{(10 \% ),} \mathrm{placed} \mathrm{in} \mathrm{boiling} \mathrm{water} \mathrm{bath} \mathrm{for} 15$ minutes. The samples were sieved through a $100 \mathrm{um}$ aperture. The pollen grains were settled in monofilament sieve (7 um), then washed with dist water.The washings were made up with dist water and centrifuged at 3,000 r. p. $\mathrm{m}$ for 3 minutes. The liquid was decanted and $10 \mathrm{ml}$ of Hydrofluoric HF (40\%) were added, boiling water bath overnight, centrifuged and decant. The pellet was resuspended in 10\% HCL, to dissolve residual silicoflorides, centrifuged and decant. The pellet resuspended in Glacial Acetic Acid to dehydrate prior to acetolysis. Acetolysed [6]. The purified samples mounted on glass slides and counted for their pollen grains up to 300 grains. Pollen identification routinely used $\times 400$ magnification with $\times 1000$ magnification for small and difficult types with reference standard keys [7], and reference herbarium collection specimens of ESRI (Environmental Studies and Research Institute) Sadat City, Minufiya University. While, pollen and spores nomenclature follows [8].

\section{Results}

Table 1 The frequencies of different pollen types in five grams soil at different depths of Qarun Lake profile.

\begin{tabular}{|c|c|c|c|c|c|c|c|c|c|c|c|c|c|c|}
\hline \multirow{2}{*}{ Chronology } & \multirow{2}{*}{$\begin{array}{l}\text { Depth/ } \\
\text { cm }\end{array}$} & \multirow{2}{*}{$\frac{\text { Pteridophy }}{\text { Lycopod }}$} & \multicolumn{4}{|c|}{ Monocot } & \multicolumn{8}{|c|}{ Dicot } \\
\hline & & & TY & $\mathrm{JU}$ & $\mathrm{PO}$ & $\mathrm{CY}$ & CAR & $\mathrm{CH}$ & $\mathrm{NY}$ & FAB & AST & TA & $\mathrm{ON}$ & LA \\
\hline \multirow{3}{*}{ Recent } & $\begin{array}{l}0-10 \\
\text { Surface }\end{array}$ & - & 0.9 & 12.6 & 24.6 & 1.0 & 6.6 & 51.2 & - & - & 0.6 & 2.5 & - & - \\
\hline & $10-20$ & - & 0.4 & - & 25.0 & 2.0 & 10.0 & 49.8 & 2.0 & - & 2.7 & 8.3 & - & - \\
\hline & $20-30$ & - & 3.4 & 2.0 & 16.8 & 4.0 & 8.0 & 36.9 & - & 8.8 & 13.4 & 2.7 & 0.8 & 3.2 \\
\hline \multirow{7}{*}{ Roman } & $30-40$ & - & - & - & 16.3 & 4.7 & 3.3 & 40.5 & 4.7 & 4.7 & 2.3 & 0.9 & 19.5 & 0.3 \\
\hline & $40-50$ & 0.9 & - & - & 7.3 & - & - & 31.8 & 10.7 & 2.7 & 2.7 & - & 31.8 & 12.0 \\
\hline & $50-60$ & - & - & - & 9.6 & 5.0 & - & 28.8 & 10.0 & 1.9 & 10.0 & - & 6.5 & 7.1 \\
\hline & $60-70$ & - & - & - & 53.6 & 7.1 & - & 20.0 & - & 7.1 & 8.5 & - & - & 3.7 \\
\hline & $70-80$ & - & - & - & 74.0 & - & - & 5.0 & - & 2.0 & 7.4 & - & 11.1 & - \\
\hline & $80-90$ & 0.9 & - & - & 83.3 & - & - & 3.3 & - & - & 3.3 & 3.3 & 3.3 & 2.3 \\
\hline & $90-100$ & 3.5 & 11.8 & 8.1 & 48.2 & 15.0 & - & 2.4 & - & - & 3.0 & 5.0 & - & 2.0 \\
\hline \multirow{2}{*}{ Greek } & $100-110$ & 5.6 & 7.0 & 10.2 & 45.5 & 14.8 & - & 3.4 & - & - & 5.0 & 2.2 & 1.1 & 5.0 \\
\hline & $110-120$ & 10.4 & 8.9 & 7.6 & 47.3 & 10.5 & - & 5.2 & - & - & 3.0 & 1.0 & - & 6.0 \\
\hline
\end{tabular}

Pteridophy = Pteridophyta; Lycopod = Lycopodium; Monocot = Monocotyledonae; TY = Typhaceae; JU = Juncaceae; PO = Poaceae (Graminae); $C Y=$ Cyperaceae $;$ Dicot = Dicotolydonae; $C A R=$ Caryophyllaceae $; C H=$ Chenopodiaceae; $N Y=N y m p h a e a c e a e ;$ $F A B=$ Fabaceae (Leguminosae); AST = Asteraceae (Compositae); $T A=$ Tamaricaceae; $O N=$ Onagraceae; $L A=$ Lamiaceae $($ Labiatae) . 


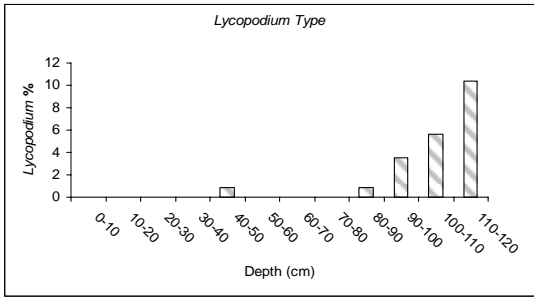

(a)

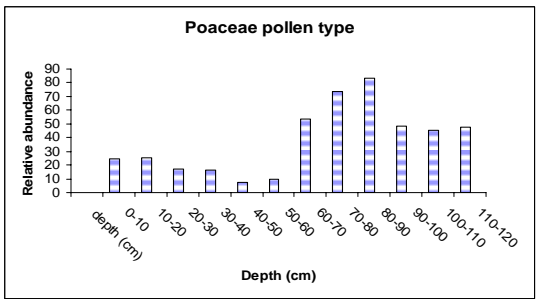

(d)

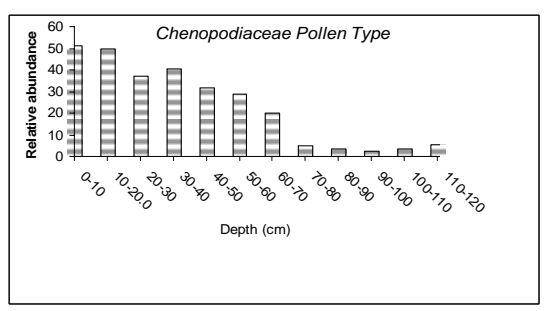

(j)

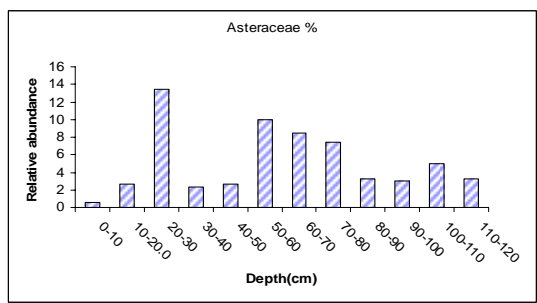

(j)

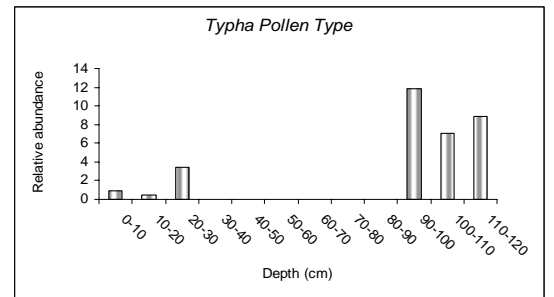

(b)

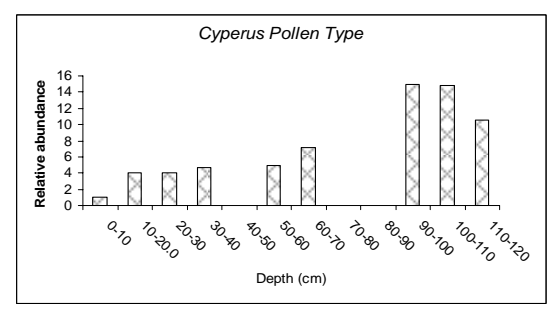

(e)

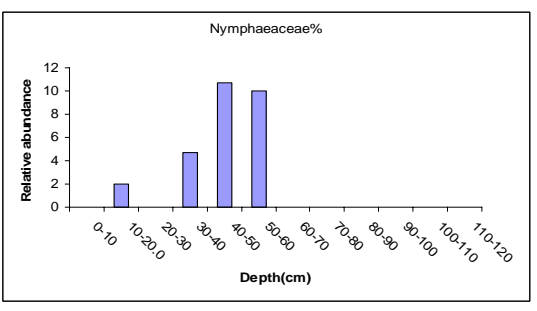

(h)

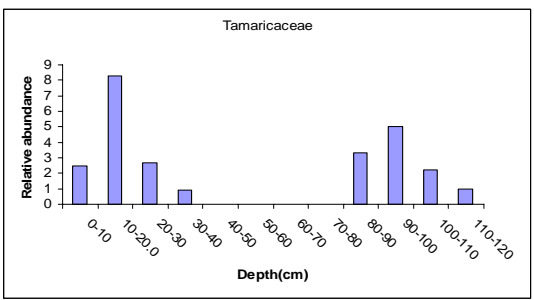

(k)

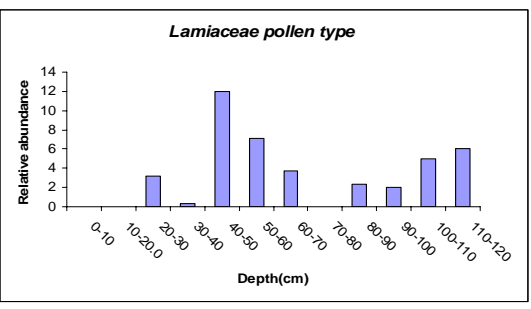

(m)

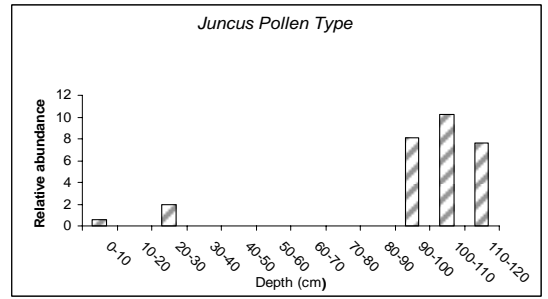

(c)

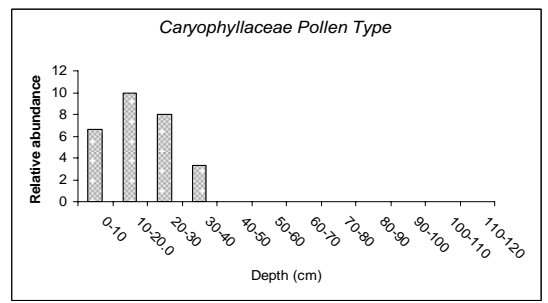

(f)

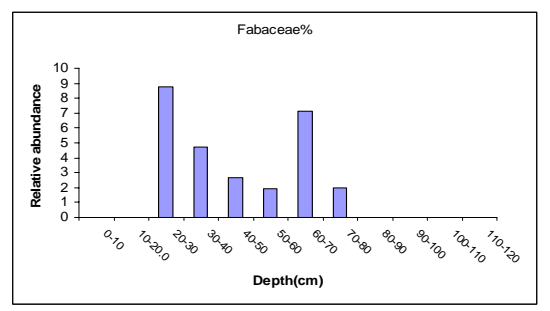

(i)

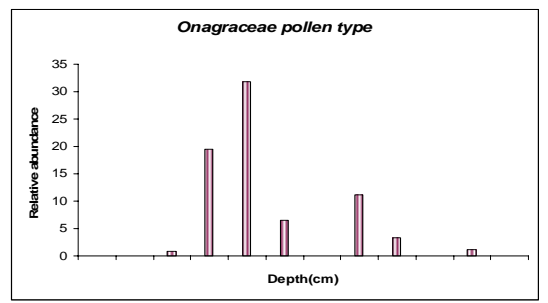

(l)

Fig. 5 Variations in the frequency of pollen grains and spores in differnt soil samples from Qarun lake profile. 


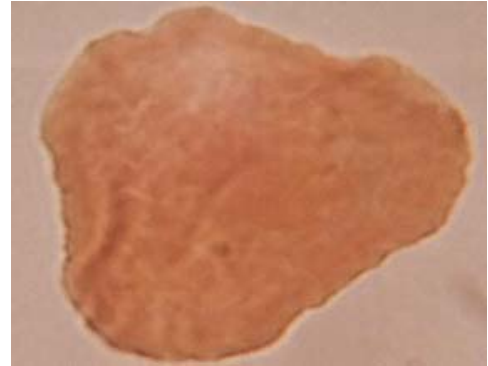

Lycopodium

(a)

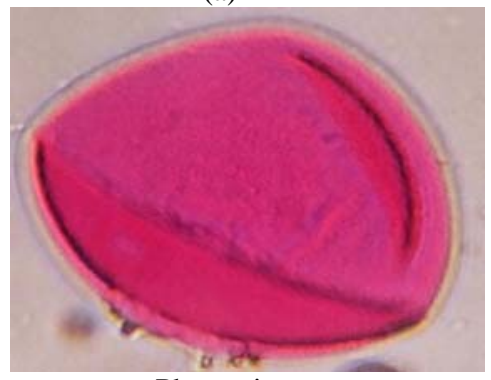

Phragmites

(d)

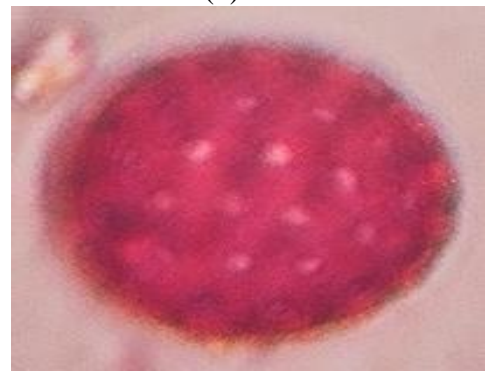

Salsola

(g)

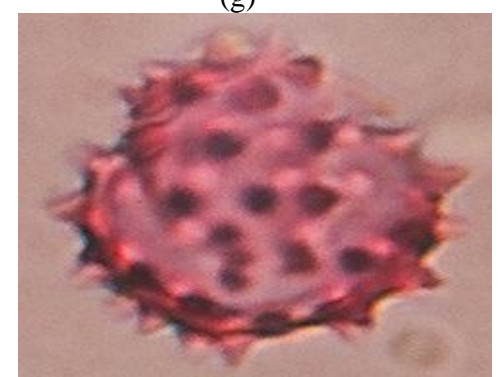

Aster

(j)

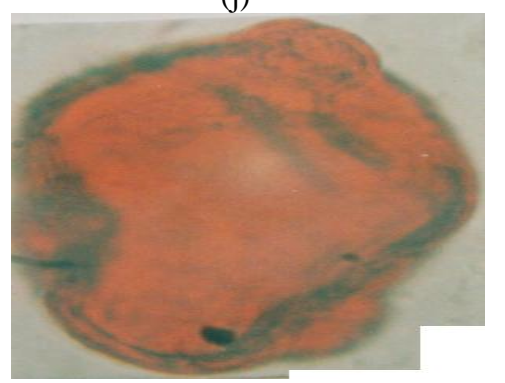

(m)

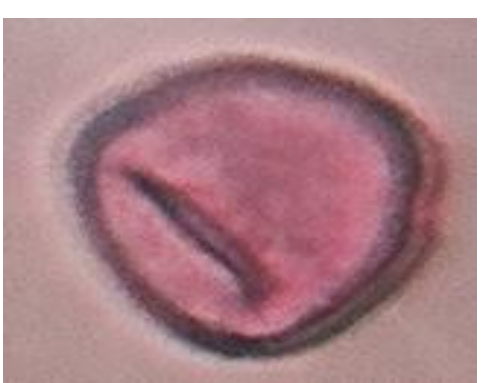

Typha

(b)

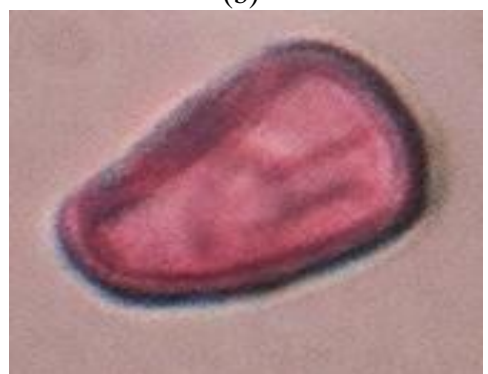

Cyperus

(e)

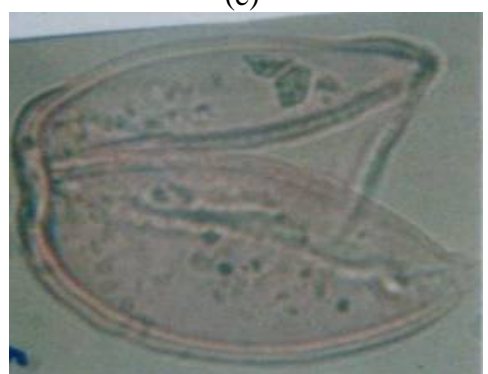

Nymphaea

(h)

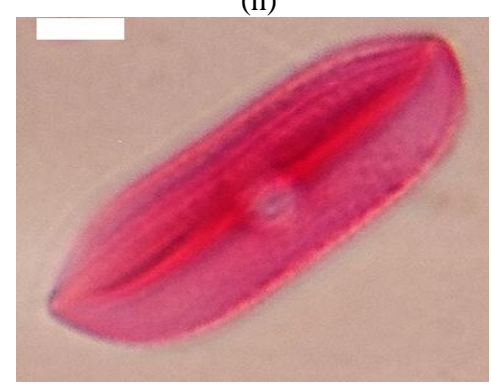

Vicia

(k)

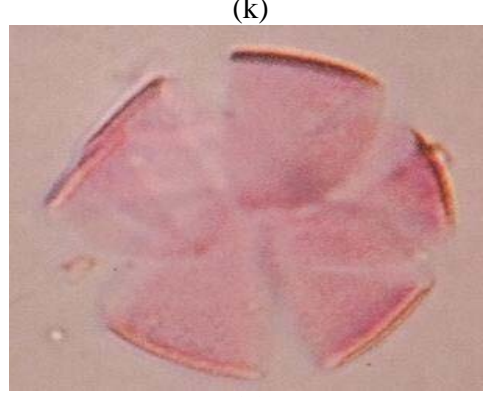

(n)

Mentha

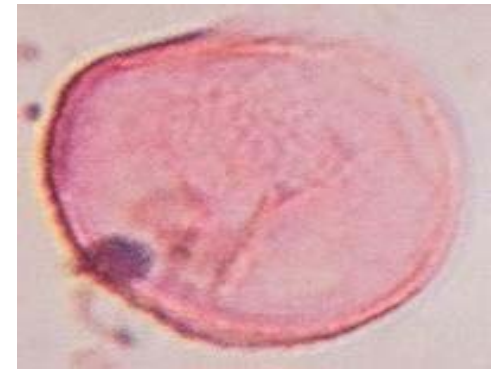

Juncus

(c)

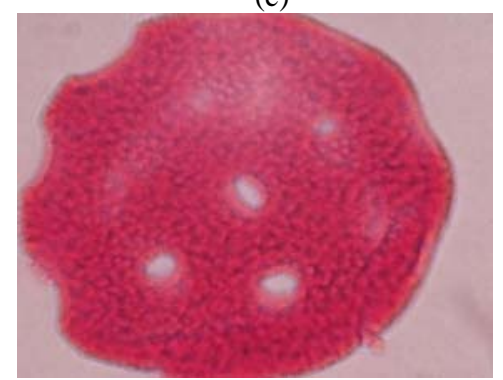

Spergularia

(f)

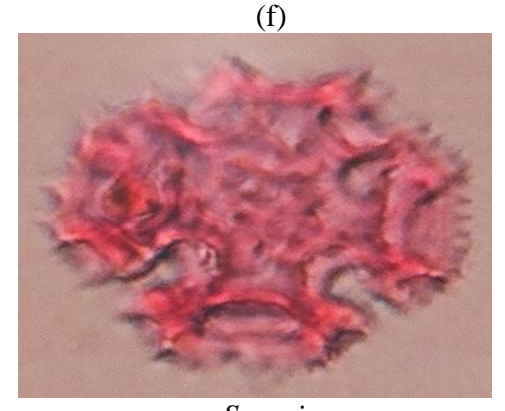

Senecio

(i)

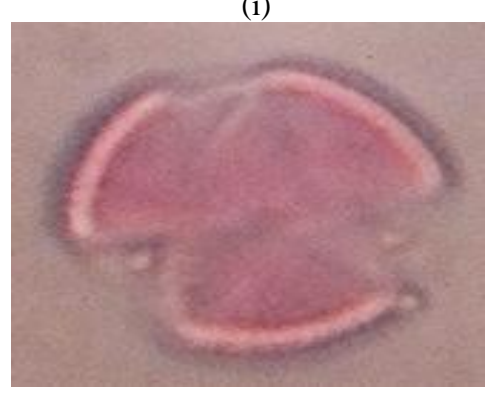

Tamarix

(l)

Fig. 6 Showing Pollen and Spores. 
Legends to Fig. 6

A- Lycopodium spore: Sexine, reticulate sculpture,trilete spore, size(49 um).

B-Typha pollen type: Spheroidal shape, monoporate, porus indistinct, exine semitectate, sexine thicker than nexine, micro-reticulate-heterobrochate sculpture, grain size (38 um).

C-Juncus pollen type: Spheroidal shape, radially symmetrical, inaperturate, size (46 um).

D-Phragmites pollen type: Monoporate, spheroid ovoid shape, porus circular, psilate granulate sculpture, grain size (36 um).

E-Cyperus pollen type: Pear like shape, inaperturate, exine, tectate-perforate and psilate sculpture, grain size (29 um).

F-Spergularia pollen type: Radially symmetrical, rounded, pore number 12-16, pantoporate, grain size (45 um).

G-Salsola pollen type: Spheroidal shape, radially symmetrical, polypantoporate, perforate sculpture, 40-45 pores, with grain size (38 um).

$\mathrm{H}$-Nymphaea pollen type: Aperture almost equals the diameter of the whole pollen grain, syncolpate, psilate to psilate scabrate sculpture, grain size (48 um).

I-Senecio pollen type: Fenestrate type, grain with coarse network of high echinate ridges separated by large lacunae, tri-or tetra-zonocoporate, grain size (42 um).

J-Aster pollen tape: Tri-lobed shape in polar view, aperture, tri-zonocolporate, echinate surface, no columellae visible, spiny wall, grain size about (35 um).

K-Vicia pollen type: The grain shape longer than broad, colpi long, suprareticulate, and endoporus well defined, aperture tri-zonocolporate,

L-Tamarix pollen type: Isopolar, radially symmetrical shape, tri-zonocolporate, reticulate sculpture, clip long, grain size (20 um).

M-Jussiaea pollen type: Simple aperture, pore situated at the corners, vestibulate, sculpture psilate at the inter pori and psilate scabrate near the vestibuli,grain size (80 um).

$\mathrm{N}$-Mentha pollen type: Elliptic shape, sex simple aperture, colpi slit shaped, mrgo present, reticulate sculpture, reticulum containuous all over the surface, grain size (49 um).

(All magnifications $1000 \times$ )

Table 2 The main results.

\begin{tabular}{|c|c|c|c|c|c|c|c|}
\hline From table and Fig. No. & Pollen type & $\begin{array}{l}\text { Depth } \\
(\mathrm{cm})\end{array}$ & Highest \% & Era & $\begin{array}{l}\text { Depth } \\
(\mathrm{cm})\end{array}$ & Lowest \% & Era \\
\hline $\begin{array}{l}\text { Table (1) and Fig (5 and 5cont } \\
\text { plate1-A) }\end{array}$ & Lycopodium spores & $110-120$ & 10.4 & $\begin{array}{l}\text { Greek } \\
\text { (300-200 B.C) }\end{array}$ & $\begin{array}{l}40-50 \& \\
80-90\end{array}$ & 0.9 & Roman \\
\hline Table (1) and Fig (5-b plate1-B) & Typhaceae Pollen & $90-100$ & 11.8 & Roman & $10-20$ & 0.4 & Recent \\
\hline Table (1) and Fig (5-c plate1-C) & Juncaceae & $0-10$ & 12.6 & Recent & $20-30$ & 2 & Recent \\
\hline Table (1) and Fig (5-d plate1-D) & Poaceae (Gramineae) & $80-90$ & 83.3 & Roman & $40-50$ & 7.3 & Roman \\
\hline Table (1) and Fig (5-e plate1-E) & Cyperaceae & $90-100$ & 15 & Roman & $0-10$ & 1 & Recent \\
\hline Table (1) and Fig (5-f plate1-F) & Caryophyllaceae & $10-20$ & 10 & Recent & $30-40$ & 3.3 & Roman \\
\hline Table (1) and Fig (5-g plate1-G) & Chenopodiaceae & $0-10-20$ & 51.2 & Recent & $90-100$ & 2.4 & Roman \\
\hline Table (1) and Fig (5-h plate1-H) & Nymphaeaceae & $40-50$ & 10.7 & Roman & $10-20$ & 2 & Recent \\
\hline Table(1)and Fig (5cont-I plate1-K) & $\begin{array}{l}\text { Fabaceae } \\
\text { (Leguminosae) }\end{array}$ & $20-30$ & 8.8 & Recent & $50-60$ & 1.9 & Roman \\
\hline Table(1)and Fig (5cont-j plate1-I \& J) & Asteraceae(Compositae) & $20-30$ & 13.4 & Recent & $0-10$ & 0.6 & Recent \\
\hline Table (1) and Fig (5cont-k plate1-L) & Tamaricaceae & $10-20$ & 8.3 & Recent & $30-40$ & 0.9 & Roman \\
\hline Table (1) and Fig (5cont-l plate1M) & Onagraceae & $40-50$ & 31.8 & Roman & $20-30$ & 0.8 & Recent \\
\hline Table (1) and Fig (5cont-m plate1-N) & Lamiaceae(Labiatae) & $40-50$ & 12 & Roman & $30-40$ & 0.3 & Roman \\
\hline
\end{tabular}

\section{Discussion}

One of the aims of palynological studies is the recognition of vegetation and plant communities on the bases of associated pollen grains. In the present study soil samples have been analysed for their pollen content. The data obtained revealed that, Lycopodium spores has been dominant during Greek Period with relative abundance $10.4 \%$ (at $110-120 \mathrm{~cm}$ ) (Table 1 ,
Fig. 5), these spores indicate a humid conditions at this period [9, 10], also recorded in Holocecne Nile Slits from the Nile Delta [11]. The above stratum was dominated with Cat tail (Typha pollen type) Typhaceae $11.8 \%$ at depth $90-100 \mathrm{~cm}$, Roman Period (30 B.C-600 A.D). These plants are well known reed swamps which indication a swampy habitat, according to Ref. [12, 13]. At the middle stratum, dating to 
middle Roman period dominated with Primerose willow (Jussiaea pollen type) Onagraceae $31.8 \%$, at (40-50 cm) depth, Sacred lotus (Nymphaea pollen type) Nymphaeaceae $10.7 \%$, (40-50 cm) depth and Budding grass (Mentha pollen type) Lamiaceae 12\% $(40-50 \mathrm{~cm})$ depth, these plants are known as Nile water, so indicating Nile flooding to the Lake Qarun during Middle Roman Period. In this connection [14, 15], reported that Jussiaea and Nymphaea indication to khor, tributaries and aquatic habitats. While, at the following stratum $(20-30 \mathrm{~cm})$ depth, dating Late Roman Period, the following plants recorded highest values, Goose foot (Chenopodium pollen type) Chenopodiaceae 36.9\%, Common groundsel (Senecio pollen type) Asteraceae $13.4 \%$ Ray grass (Lolium pollen type) Poaceae 16.8\%, and Common Vetch (Vicia pollen type) Fabaceae 8.8\%, these plants were classified mesophytic, which indicating mesophytic habitats at Late Roman Period [16]. At surface stratum (0-10 cm and 10-20 cm), dating recent time, recorded the highest abundance of the following; Salt wort (Salsola pollen type) Chenopodiaceae 51.2\%, Sharp rush(Juncus pollen type) Juncaceae 12.6\%, Sand spurrey (Spergulria pollen type) Caryophyllaceae 10\%,and Tamarisk salt tree (Tamarix pollen type) Tamaricaceae $8.3 \%$, these plants are known as salt loving or halophytic so, it supporting halophytic and salt marsh habitats. In this connection, Abd El-Fattah [17] reported that, Salsola and Spergularia were from wet halophytic plants, also, El-Shenbary [18] mentioned that Juncaceae and Chenopodiaceae were a salt marsh plants, while Tamarix and Casuarina were flourish under arid and hot climate. Some pollen types recorded few representations; this may due to wind dispersion from another sites. For lakes and marine sites where water borne pollen are the major influx, the assemblage must be varied in all values [19]. This is directly comparable to some high resolution pollen and spores diagrams from laminated lake sediments which typically show these high-frequency fluctuations in values [20]. The dramatic changes in land cover, this accords with the general dampened response of many lake diagrams to human impact [21]. For more information about the claimatic change in the ancinet Egypt, please return to Ref. [22-25].

\section{References}

[1] Dinacauze, D. F., 2000. Environmental Archaeology, Principales and Practice. UK: Cambridge University Press.

[2] West, R. G., 1971. Studying the Past by Pollen Analysis. UK: Oxford University Press.

[3] Mehringer, J. R., Petersen, K. L., and Hassan, F. A. 1979. "A Pollen Record from Birkket Qarun and the Recent History of the Fayum, Egypt.” Quaternary Research 11: 238-56.

[4] Hassan, F., Tassie, G., Flower, R., M. nd Hamden, M. 2006. "Modeling Environmental and Settlement Change in the Fayum.” Egyptian Archaeology 29: 37-40.

[5] Faegri, K., and Iversen, J. 1989. Text Book of Pollen Analysis. 4th ed., edited by Kaland, K., and Krzywinski, K., Chichester: John Wiley and Sons.

[6] Moore, P. D., Webb, J. A., and Collinson, M. E. 1991. Pollen Analysis, Second Edition. Oxford: Blackwell Science Publications, p. 216.

[7] Andrew, R. 1984. Practical Pollen Guide to the British Flora. QRA Technical Guide, No. 1, QRA. Cambridge.

[8] Bennett, K. D., Whiittington, G., and Edwards, K. J., 1994. "Plant Nomenclatural Changes and Pollen Morphology in the British Isles.” Quaternary Newsletter 73: 1-6.

[9] Rossignol, M., 1962. Analysis of Sediments Marine Pollen Quaternnires in Israel. II Sediments Plleistocenes, Pollen et Spores, IV, I, pp. 121-84.

[10] Rossignol, M., 1969. Sedimentation in the Quaternary palynological Marine area of Palestine: a study of paleoenvironment, Notes and Mem. Moyyyyen east, X, Nature, Paris, p. 272.

[11] Saad, S. I., and Sami, S., 1967. Studies of Pollen and Spores Content of the Nile Delta Deposits. Pollen and Spores, (Berenbal), Paris, pp. 476-503.

[12] Ritchie, J. C., 1985. Modern Pollen Spectra from Dakhla Oasis, Western Egyptian Desert. Grana, Uppsala, 1984, pp.1-6.

[13] Ayyad, S. M., 1988. "Pollen Grain Ecology of the Mediterranean Sea Coast Egypt.” Ph.D. Thesis, Mansura University, Egypt. pp. 136-40.

[14] Patel, V. C., Skvarla, J. J., and Raven, P. H. 1984. "Pollen Characters in to the Delimitation of Myrtales.” Ann. Mo. 
Bot. Gard. 71: 858-965.

[15] El-Ghazali, G., 1989. "A Study on the Pollen Flora of Sudan.” Ph.D. Thesis. Univ. of Bergen. Botanical Institute.

[16] El-Hadidi, M. N. 1985. "Food Plants of Prehistoric and Predynastic Egypt.” In: Plants for Arid Lands, edited by Wickens, G. E., Gooden, J. R. and Field, D. V. London: George Allen and Unwin, pp. 87-92.

[17] Abd El-Fattah, R. I. 1990. "Ecological Studies on the Adjustment of the Plants to Their Environments.” Ph.D. Thesis, Fac. Sci., Zagazig University, Egypt.

[18] El-shenbary, S. H., 1985. “A Study of Recent Changes in Vegetation Composition in the North Western Coastal Desert of Egypt in Burg El-Arab Area.” M.Sc. Thesis, Tanta University, Egypt.

[19] Brown, A. G., Carpenter, R. G., and Walling, D. E., 2007. "Monitoring Fluvial Pollen Transport, Its Relationship to Catchments Vegetation and Implications for Palaeoenvironmental Studies.” Palaeobotany and Palynology 147: 60-76.

[20] Kerig, T., Lechterbeck, J., 2004. "Laminated Sediments, Human Impact, and Multivariate Approach: A Case Study in Linking Palynology and Archaeology (Steisslingen, South-West Germany). Quaternary
International 113: 19-39.

[21] Brown, A. G., Hatton, J., OBrien, C. E., Shelby, K. A., Langdone, P. G., Stuijts, I., Caaseldine, C. J., 2005. "Vegetation, Landscape and Human Activity in Midland Ireland: Mire and Lake Records from the Lough Kinale-Derragh Lough Area, Central Ireland.” Vegetation History and Archaeobotany 14: 81-98.

[22] Shaltout, M. A. M, 2006. "Solar Activity and the Nile Flooding in Egypt from Pre-history to 20th Century." Journal of History of Geophysics and Cosmical Physics VII (1): 181-94.

[23] Shaltout, M. A. M, and Azzazi, M. F, 2014. "Climate Change in the Nile Delta from Prehistoric to the Modern Era and Their Impact on Soil and Vegetation in Some Archaeological Sites.” Journal of Earth Science and Engineering 4 (2014) 632-42.

[24] Shaltout, M. A. M., and Tadros, M. T. Y. 1990, "Variation of the Solar Activity and Irradiance, and Their Influence on the Flooding of the River Nile.” Mausam 41: (3) 393-402.

[25] Shaltout, M. A. M., and Tadros, M. T. Y. 1990, "Correlation Analysis between the Sunspots and the Nile Flood.” Mausam 41 (4) 565-8. 